\title{
Deformation Patterns of an Accretionary Wedge in the Transition Zone from Subduction to Collision offshore Southwestern Taiwan
}

\author{
Char-Shine Liu, Institute of Oceanography, National Taiwan University, Taipei, 106, Taiwan. \\ csliu@ntu.edu.tw. \\ Benoit Deffontaines, Ecole Pratique des Hautes Etudes, 15 Bd de la Mer, 35 Dinard, France \\ Chia-Yu Lu, Department of Geosciences, National Taiwan University, 106, Taiwan \\ Serge Lallemand, Département de Tectonique, Université de Montpelliers, France
}

\section{Abstract}

The area offshore southwestern Taiwan is the place where the Luzon subduction complex first encroaches on the passive Chinese continental margin. Distinctive fold-and-thrust structures of the convergent zone and horst-and-graben structures of the passive margin are separated by a deformation front that extends NNW-ward from the eastern edge of Manila Trench and Penghu Canyon to the foot of the continental slope. Due to the outgrowth of the accretionary wedge as the influx of orogenic sediments increases toward Taiwan, the trend of the frontal folds and thrusts of the submarine accretionary wedge changes from a NNE-SSW direction near Luzon Island to a NW-SE direction north of $20^{\circ} \mathrm{N}$. The NE-SW trending Chinese continental margin blocks the westward advance of the growing accretionary wedge, forces the NW-SE trending ramp anticlines gradually turning into a NNE-SSW trending direction across the continental slope and the Kaoping Shelf, then connects to the frontal thrusts of the mountain belt on land Taiwan. The Kaoping shelf and slope are frontal portions of the submarine incipient collision zone that are separated from the South China Sea shelf and slope by the Penghu submarine canyon. Presence of the complex Penghu submarine canyon system made exact location of the deformation front and nature of many morphotectonic features offshore SW Taiwan unclear.

Swath bathymetry data and seismic reflection profiles collected during the ACT cruise of the R/V l'Atalante in 1996 and seismic data from several recent $\mathrm{R} / \mathrm{V}$ Ocean Researcher I cruises provide insights on differentiating morphological and structural characters of the anticlinal folds of the accretionary wedge and the slope hills of the passive continental margin. A high-resolution digital terrain model (DTM) of the SW Taiwan offshore area has been generated. Based on the analyses of the seismic reflection profiles and interpretation of various morphologic features revealed from high-resolution bathymetry maps, we found that the deformation front offshore SW Taiwan does not appear as a single structural front. In stead, a series of N-S-trending fold-and-thrust structures that terminate sequentially in an en echelon pattern along the passive Chinese continental slope act as the deformation front. The termination points of the frontal folds extend northeastward along the Chinese continental slope to onshore Taiwan near Tainan.

Besides the fold-and-thrust structures, shaded bathymetric maps produced from the DTM also reveal many topographic lineaments. A prominent NE-SW trending lineament, named the Yung-An lineament, forms the southeastern boundary of the Penhu submarine canyon system. The drainage pattern of the Penhu submarine canyon system has been influenced by linear fractures that cut across ramp anticlines in the frontal portion of the accretioary wedge. Slop gradient and dip direction maps derived from the DTM provide clear indications that tectonic processes played significant roles in shaping the drainage pattern of the Penghu submarine canyon system.

Distinctive morphotectonic features in the area offshore southwestern Taiwan reflect the transition from subduction to collision. South of $21^{\circ} 20^{\prime} \mathrm{N}$, Manila Trench, Hengchun Ridge (accretionary wedge), North Luzon Trough (forearc basin) and Luzon Arc consist of major morphotectonic units in the subduction system. This simple oceanic subduction configuration evolves into a continental subduction north of about $21^{\circ} 30^{\prime} \mathrm{N}$, and arc-continent collision on land Taiwan, as the passive Chinese continental margin enters the 
subduction system obliquely. The presence of Chinese continental margin has a major effect on the deformation pattern of the frontal Luzon accretionary wedge offshore SW Taiwan. A basement high (the Peikang High) in the Chinese continental margin acts as an indenter that causes tectonic escape of Southwest Taiwan toward southwest. Topographic lineaments observed in this study that cut across the fold-and-thrust structures of the accretionary wedge provide strong evidences for the lateral expulsion of SW Taiwan. 